\title{
TUNTUTAN HAK DALAM PERSIDANGAN PERKARA PERDATA
}

\author{
Rahadi Wasi Bintoro \\ Fakultas Hukum Universitas Jenderal Soedirman, Purwokerto, Jawa Tengah \\ e-mail: rahadiwasi@yahoo.co.id
}

\begin{abstract}
Procedure of private law in Indonesia have experiencing of some growths, for the example is the mechanism of suing which it's not arranged in Het Herzeine Indonesich Reglement, such as class action, legal standing, citizen lawsuit or actio popularis. This article is study to the difference characteristic of suing in procedure of private law in Indonesia. Pursuant to analysis result, the mechanism of ordinary suing is the mechanism suing by the plaintiff to the sued as effect of contempt of court or break a promise which it have generated loss to plaintiff. Class action is the mechanism of suing by numerous plaintiff which it raised by class representative, that representing his own and his group member, with demand in the form of indemnation. Suing of non government organization (NGO) or legal standing is the mechanism of proffering suing by NGO as collision effect or existence of contempt of court which done by the people which arranged in statues. Citizen lawsuit or actio popularis is a suing that raised by citizen to state, as effect of existence of contempt of court, in the form of neglected the civil rights. Its purpose is formed the law order immediately.
\end{abstract}

Keyword: suing, private dispute, plaintiff, sued

\begin{abstract}
Abstrak
Hukum acara perdata di Indonesia, mengalami beberapa perkembangan, salah satu contohnya adalah mekanisme pengajuan tuntutan hak di luar ketentuan yang diatur di dalam Het Herzeine Indonesich Reglement, seperti class action, legal standing dan citizen lawsuit atau actio popularis. Artikel ini membahas mengenai perbedaan karakteristik masing-masing tuntutan hak tersebut. Berdasarkan hasil analisis, mekanisme pengajuan gugatan biasa merupakan mekanisme pengajuan tuntutan hak oleh penggugat kepada tergugat sebagai akibat perbuatan wanprestasi atau perbuatan melawan hukum tergugat yang telah menimbulkan kerugian pada diri penggugat. Gugatan class action merupakan mekanisme pengajuan tuntutan hak oleh penggugat yang jumlahnya sangat banyak dimana gugatan diajukan oleh wakil kelompok, yang mewakili kepentingannya sendiri maupun anggota kelompoknya, dengan tuntutan berupa ganti kerugian. Gugatan LSM atau legal standing merupakan mekanisme pengajuan gugatan oleh LSM sebagai akibat pelanggaran atau adanya perbuatan melawan hukum yang dilakukan pihak lain yang merupakan kegiatan perlindungan yang dilakukan LSM tersebut sebagaimana diatur dalam anggaran dasar. Gugatan citizen lawsuit atau actio popularis, merupakan gugatan yang diajukan oleh seorang atau lebih warga negara atas nama seluruh warga negara yang ditujukan kepada negara, dalam hal ini penyelenggara negara, sebagai akibat adanya perbuatan melawan hukum, pada umumnya berupa penelantaran hak-hak warga negara, dengan maksud agar segera dibentuk aturan hukum.
\end{abstract}

Kata Kunci: tuntutan hak, perkara perdata, penggugat, tergugat

\section{A. Pendahuluan}

Konsekuensi suatu negara hukum adalah menempatkan hukum di atas segala kehidupan bernegara dan bermasyarakat. Negara dan masyarakat diatur dan diperintah oleh hukum, bukan diperintah oleh manusia. Hukum berada di atas segala-segalanya, kekuasaan dan penguasa tunduk kepada hukum.

Hubungan yang menimbulkan hak dan kewajiban telah diatur dalam peraturan hukum disebut hubungan hukum. Hubungan hukum adalah hubungan yang diatur oleh hukum dan menjadi obyek hukum. Dalam hukum perdata 
diatur tentang hak dan kewajiban orang-orang yang mengadakan hubungan hukum yang meliputi peraturan yang bersifat tertulis berupa peraturan perundang-undangan dan yang bersifat tidak tertulis berupa peraturan hukum adat dan kebiasaan yang hidup di dalam masyarakat.

Pelaksanaan hukum materiil, khususnya hukum materiil perdata, dapatlah berlangsung secara diam-diam di antara para pihak yang bersangkutan tanpa melalui pejabat atau instansi resmi. Namun demikian dapat terjadi suatu kemungkinan, bahwa hukum materiil perdata itu dilanggar, sehingga ada pihak yang dirugikan dan terjadilah gangguan keseimbangan kepentingan di dalam masyarakat. Dalam hal ini, hukum materiil perdata yang telah dilanggar itu haruslah dipertahankan atau ditegakkan. ${ }^{1}$ Hal ini disebabkan, karena setiap warga negara memiliki hak yang sama dihadapan hukum dan ia pun berhak untuk membela haknya apabila ia merasa dirugikan oleh pihak lain. Apabila dalam suatu hubungan hukum khususnya yang bersifat obligatur, salah satu pihaknya tidak melaksanakan kewajiban, maka pada pihak lain terdapat pelanggaran hak, sehingga dalam hal ini terdapat suatu sengketa.

Penyelesaian sengketa dapat dibedakan antara penyelesaian sengketa secara damai dan penyelesaian sengketa secara adversarial. Penyelesaian sengketa secara damai lebih dikenal dengan penyelesaian secara musyawarah mufakat. Sementara penyelesaian sengketa secara adversrial lebih dikenal dengan penyelesaian sengketa oleh pihak ketiga yang tidak terlibat dalam sengketa. ${ }^{2}$

Dalam penyelesaian sengketa secara damai tidak ada pihak yang mengambil keputusan bagi penyelesaian sengketa. Keterlibatan pihak ketiga dalam penyelesaian sengketa secara damai adalah dalam rangka mengusahakan agar para pihak yang bersengketa dapat sepakat

\footnotetext{
Sudikno Mertokusumo, 2002, Hukum Acara Perdata Indonesia, Yogyakarta: Liberty, hlm. 2

2 Hikmahanto Juwana, 2009, Arbitrase sebagai Forum Penyelesaian Sengketa, Workshop Arbitrase sebagai Alternatif Penyelesaian Sengketa Bisnis, diselenggarakan pada tanggal 30-31 Mei 2009, Purwokerto: Alsa Fakultas Hukum UNSOED
}

untuk menyelesaian sengketa mereka. Bentuk dari penyelesaian sengketa secara damai adalah negosiasi, mediasi dan konsiliasi. Negosiasi adalah penyelesaian sengketa secara damai dimana para pihak berhadapan langsung tanpa ada keikutsertaan dari pihak ketiga. Sementara mediasi dan konsiliasi adalah penyelesaian sengketa secara damai dimana ada turut campur pihak ketiga. Perbedaan antara konsiliasi dan mediasi terletak pada aktif-tidaknya pihak ketiga dalam mengusahakan para pihak untuk menyelesaikan sengketa. Apabila dilihat dari sifat penyelesaian sengketa secara damai, maka penyelesaian ini merupakan hal yang ideal mengingat keadilan muncul dari para pihak.

Penyelesaian sengketa secara adversarial diselesaikan melalui suatu lembaga penyelesaian sengketa. Ada dua bentuk lembaga penyelesaian sengketa. Pertama adalah lembaga penyelesaian sengketa yang disediakan oleh non negara atau swasta yang disebut sebagai "Arbitrase". Kedua adalah lembaga penyelesaian sengketa yang disediakan oleh negara yang disebut dengan istilah "Pengadilan". ${ }^{3}$

Dalam penyelesaian sengketa melalui arbitrase keadilan untuk para pihak yang bersengketa berasal dari arbiter. Penyelesaian melalui arbitrase menghasilkan putusan. Hukum di Indonesia yang mengatur tentang arbitrase adalah Undang-undang Nomor 30 Tahun 1999 tentang Arbitrase dan Alternatif Penyelesaian Sengketa.

Selain itu, penyelesaian sengketa perdata juga dapat dilakukan melalui jalur lembaga pengadilan. Salah satu unsur negara hukum adalah berfungsinya kekuasaan kehakiman yang merdeka yang dilakukan oleh badan peradilan. Pemberian kewenangan yang merdeka tersebut merupakan "katup penekan" (pressure valve), atas setiap pelanggaran hukum tanpa kecuali. Pemberian kewenangan ini dengan sendirinya menempatkan kedudukan badan peradilan sebagai benteng terakhir (the last resort) dalam upaya penegakan "kebenaran" dan "keadilan". Dalam hal ini tidak ada badan lain yang berkedudukan sebagai tempat mencari penegakan

3 loc.cit. 
kebenaran dan keadilan (to enforce the truth and justice) apabila timbul sengketa atau pelanggaran hukum. ${ }^{4}$

Kekuasaan kehakiman adalah Kekuasaan Kehakiman adalah kekuasaan negara yang merdeka untuk penyelenggarakan peradilan guna menegakkan hukum dan keadilan berdasarkan Pancasila dan Undang-Undang Dasar Negara Republik Indonesia Tahun 1945, demi terselenggaranya Negara Hukum Republik Indonesia. ${ }^{5}$ Pengertian kekuasaan Negara yang merdeka, dimaksudkan, bahwa kekuasaan kehakiman terpisah dari kekuasaan pemerintahan dan Kekuasaan Perundang-undangan serta merdeka dari pengaruh kedua kekuasaan itu. Untuk hal tersebut dengan jelas dapat dijumpai dalam penjelasan resmi pasal 24 dan 25 UUD ' 45. Bahkan penjelasan tersebut masih menguraikan sebuah harapan yakni: “...Berhubung dengan itu, harus diadakan jaminan dalam Undang-undang tentang kedudukan para hakim". Jaminan tentang kedudukan para hakim yang dimaksud dalam kaitan ini tidak lain adalah jaminan kemandirian hakim sebagai aparatur penyelenggaraan peradilan.

Proses penyelesaian perkara perdata di pengadilan telah diatur dalam hukum acara perdata. Hukum acara perdata atau hukum formil perdata adalah alat untuk menyelenggarakan hukum materiil, sehingga hukum acara itu harus digunakan sesuai dengan keperluan hukum materiil dan hukum acara tidak boleh digunakan apabila bertentangan dengan hukum materiil. ${ }^{6}$ Berdasarkan pengertian tersebut, maka esensi hukum acara Perdata adalah mengatur cara bagaimana orang yang kepentingan privatnya dilanggar oleh orang lain itu dapat diselesaikan, cara bagaimana seseorang dipulihkan haknya apabila dilanggar orang lain dan cara bagaimana yang berwenang atau pengadilan menyelesaikan atau memulihkan sengketa perdata. Untuk memulihkan hak seseorang

\footnotetext{
${ }^{4}$ M. Yahya Harahap, Beberapa Tinjauan Sistem Peradilan Dan Penyelesaian Sengketa, Bandung: PT. Citra Aditya Bakti, hlm. 34

5 Pasal 1 Undang-Undang Nomor 48 Tahun 2009 tentang Kekuasaan Kehakiman, LNRI Tahun 2009 No. 5076

6 G. Wijers, 2000, Het Gezag van Gewijsde in Burgerlijke Landraad zaken, dalam Supomo, Hukum Acara Perdata Pengadilan Negeri, Jakarta: Pradnya Paramita, hlm. 10
}

yang dilanggar, maka dilakukan upaya hukum melalui pengajuan tuntutan hak melalui pengadilan.

Tugas pengadilan, dalam hal ini adalah hakim, yaitu untuk memeriksa, memutus, dan mengadili perkara perdata. Peradilan perdata dilakukan dengan mendasarkan pada peraturan perundang-undangan seperti HIR (Het Herzeine Indonesish Reglement), Rbg (Rechtsreglemeent Buitengewesten), Rv (Reglement op de burgerlijke recht Vordering), Undang-undang No. 20 Tahun 1947, Undang-undang No. 48 Tahun 2009 tentang Kekuasaan Kehakiman.

Pada mulanya, pengajuan tuntutan hak yang dikenal hanya pengajuan tuntutan hak melalui gugatan biasa, yaitu pengajuan tuntutan hak oleh subjek hukum yang satu kepada subjek hukum lainnya atas suatu sengketa keperdataan, baik berupa wanprestasi maupun perbuatan melawan hukum, dimana pada diri pihak yang mengajukan tuntutan hak (gugatan) mengalami kerugian langsung maupun kerugian meteriil sebagai akibatnya. Namun demikian, dalam perkembangannya, pengajuan tuntutan hak dapat diajukan melalui mekanisme class action, legal standing dan citizen lawsuit.

Berdasarkan hal tersebut, maka penulis tertarik untuk membahas mengenai perbedaan karakteristik antara pengajuan tuntutan hak dalam persidangan perkara perdata melalui mekanisme pengajuan gugatan biasa, class action, legal standing dan citizen lawsuit.

\section{Pembahasan}

Kepastian hukum sebagaimana keadilan dan kemanfaatan hukum sesungguhnya merupakan sebuah doktrin. Doktrin kepastian hukum mengajarkan kepada setiap pelaksana dan penegak hukum untuk (demi terkendalikannya kepatuhan warga agar ikut menjaga ketertiban dalam setiap aspek kehidupan) mendayagunakan hukum yang sama untuk kasus yang sama. Inilah doktrin kaum positivis, yang dikenali pula sebagai doktrin the supreme state of (national) law yang mengajarkan dan meyakini adanya status hukum yang mengatasi kekuasaan dan otoritas lain. Doktrin ini memiliki konsekuensi pada ajaran lebih lanjut, bahwa setiap ahli 
hukum, khususnya yang tengah bertugas sebagai hakim, tidak menggunakan rujukan-rujukan normatif lain selain yang terbilang norma hukum guna menghukumi suatu perkara. ${ }^{7}$

Hakim tidak boleh menolak suatu perkara dengan alasan tidak tahu atau tidak ada dasar hukumnya. ${ }^{8}$ Hukum acara perdata di Indonesia, mengalami beberapa perkembangan, salah satu contohnya adalah mekanisme pengajuan tuntutan hak di luar ketentuan yang diatur di dalam Het Herzeine Indonesich Reglement Staatsblaad No. 16 tahun 1848, seperti class action, legal standing dan citizen lawsuit atau actio popularis. Berikut ini penulis paparkan kharakteristik dari keempat mekanisme pengajuan tuntutan hak tersebut.

\section{Tuntutan Hak/ Gugatan Biasa}

Pada dasarnya pihak yang bersengketa dalam perkara perdata terdiri dari dua pihak, yaitu penggugat dan tergugat. Dalam hal ini, perkara tersebut mengandung sengketa, atau yang kemudian dikenal dengan peradilan contentiosa atau contentious jurisdiction, yaitu kewenangan peradilan yang memeriksa perkara yang berkenaan dengan masalah persengketaan (jurisdiction of court that is concerned with contested matters) antara pihak yang bersengketa (between contending parties) ${ }^{9}$. Penggugat merupakan pihak yang merasa haknya telah dilanggar oleh pihak lain (tergugat). Pengajuan tuntutan hak dalam perkara perdata dapat diajukan secara lisan maupun tertulis. Bentuk tertulis inilah yang kemudian dikenal sebagai surat gugatan. HIR dan Rbg hanya mengatur tentang cara bagaimana mengajukan gugatan. Persyaratan mengenai gugatan terdapat dalam Pasal 8 no. 3 Rv, yang meliputi :

Pertama, identitas para pihak, berisi mengenai nama lengkap, umur/tempat tanggal lahir, pekerjaan dan alamat/domisili. Namun demikian, ada kalanya kedudukan sebagai peng-

\footnotetext{
7 Soetandyo Wignjosoebroto, 2006, Menggagas Terwujudnya Peradilan Yang Independen Dengan Hakim Profesional Yang Tidak Memihak. Buletin Komisi Yudisial.

8 Pasal 10 ayat (1) Undang-undang No. 48 Tahun 2009 tentang Kekuasaan Kehakiman

9 Henry Campbell Black, 1978, Black Law Dictionary, St Paul Minn: West Publishing, hlm. 289
}

gugat/tergugat dilakukan oleh cabang suatu badan hukum, oleh karenya harus dijelaskan mengenai $\mathrm{BH}$ tersebut. Kedua, posita/fundamentum petendi, posita merupakan dalil-dalil konkrit tentang adanya hubungan hukum yang merupakan dasar serta alasan-alasan dari tuntutan (middelen van den eis). Posita terdiri dari dua bagian yaitu bagian yang menguraikan tentang kejadian-kejadian/peristiwa hukum dan bagian yang menguraikan hukumnya, yaitu uraian tentang adanya hak atau hubungan hukum yang menjadi dasar yuridis dari tuntutan. Ketiga, petitum yang merupakan bagian dari surat gugatan yang berisi hal-hal yang dimohonkan untuk diputuskan oleh hakim. Petitum terdiri dari dua bagian, yaitu petitum pokok/Primer yang berisi hal-hal/tuntutan pokok yang di mohonkan untuk dikabulkan oleh pengadilan, seperti menuntut putusnya perjanjian dengan ditambah ganti rugi atau menuntut pelaksanaan perjanjian dengan uang paksa. Bagian kedua, yaitu petitum subsidair, yang berisi hal-hal yang memberi kebebasan pada hakim untuk mengabulkan lain dari petitum primair.

Pengajuan tuntutan hak melalui gugatan biasa merupakan suatu pengajuan tuntutan hak oleh subjek hukum yang satu kepada subjek hukum lainnya atas suatu sengketa keperdataan, baik berupa wanprestasi maupun perbuatan melawan hukum, dimana pada diri pihak yang mengajukan tuntutan hak (gugatan) mengalami kerugian langsung maupun kerugian meteriil sebagai akibatnya.

Berdasarkan pengertian tersebut, maka unsur-unsur pengajuan gugatan biasa yang dikenal dalam HIR, Rbg maupun Rv meliputi, pertama, adanya tuntutan hak. Tuntutan hak dalam hal ini disebabkan tidak dilaksanakannya kewajiban oleh pihak lain secara sukarela atau sesuai dengan kesepakatan para pihak, sehingga terdapat pelanggaran hak pada pihak satunya. Tuntutan hak dalam surat gugatan dimasukkan dalam petitum, yang dapat berupa petitum primer maupun subsidair. Petitum pokok/primer yang berisi hal-hal/tuntutan pokok yang di mohonkan untuk dikabulkan oleh pengadilan, seperti menuntut putusnya perjanjian dengan ditambah ganti rugi atau menuntut pelaksanaan 
perjanjian dengan uang paksa. Bagian kedua, yaitu petitum subsidair, yang berisi hal-hal yang memberi kebebasan pada hakim untuk mengabulkan lain dari petitum primair.

Tuntutan hak dalam suatu perkara perdata dapat disebabkan karena wanprestasi mau pun perbuatan melawan hukum. Wanprestasi terjadi manakala pada pihak debitur tidak melaksanakan kewajiban dan bukan karena keadaan memaksa. Debitur melakukan wanprestasi apabila tidak melakukan apa yang disanggupi untuk dilakukan, melakukan apa yang di janjikan, tetapi tidak sebagaimana yang diperjanjikan, melakukan apa yang diperjanjikan tetapi terlambat, atau melakukan sesuatu yang menurut perjanjian tidak boleh dilakukan. ${ }^{10}$

Perbuatan melawan hukum terjadi apabila perbuatan itu bertentangan dengan hukum pada umumnya. Hukum dalam hal ini, bukan saja berupa ketentuan-ketentuan tertulis, tetapi juga aturan-aturan hukum tidak tertulis, yang harus ditaati dalam hidup bermasyarakat. Kerugian yang ditimbulkan itu harus disebabkan karena perbuatan yang melawan hukum itu, antara lain kerugian-kerugian dan perbuatan itu harus ada hubungannya yang langsung; kerugian itu disebabkan karena kesalahan pembuat. Terdapat suatu kesalahan apabila pada pelaku ada kesengajaan atau kealpaan (kelalaian). Perbuatan melawan hukum tidak hanya terdiri atas satu perbuatan, tetapi juga dalam tidak berbuat sesuatu. Dalam KUH Perdata ditentukan pula bahwa setiap orang tidak saja bertanggungjawab terhadap kerugian yang disebabkan karena perbuatannya sendiri, tetapi juga terhadap kerugian yang ditimbulkan karena perbuatan orang-orang yang ditanggungnya, atau karena barang-barang yang berada di bawah pengawasannya. Substansi dari perbuatan melawan hukum adalah yaitu bertentangan dengan kewajiban hukum si pelaku, atau melanggar hak subjektif orang lain, atau melanggar kaidah tata susila (goede zeden), atau bertentangan dengan azas "Kepatutan", ketelitian serta sikap hatihati dalam pergaulan hidup masyarakat.

\footnotetext{
${ }^{10}$ Subekti, 2002, Hukum Perjanjian, Jakarta: Intermasa, hlm. 45
}

Kedua, oleh subjek hukum yang satu kepada subjek hukum yang lain. Subjek hukum merupakan pemangku hak dan kewajiban. Subjek hukum dapat berupa orang maupun badan hukum. Badan hukum sendiri dapat di bedakan menjadi badan hukum publik maupun badan hukum privat. Badan hukum publik contohnya adalah negara yang pelaksanaan tugasnya di lakukan oleh pemerintah dan lembaga-lembaga negaranya. Contoh pemerintah sebagai subjek hukum dalam lapangan hukum perdata yaitu perjanjian mebeler antara suatu pemerintah daerah dengan suatu perusahaan. Dalam contoh tersebut, pemerintah daerah mempunyai hak untuk mendapatkan mebeler yang diperjanjikan dan mempunyai kewajiban untuk membayar biaya atau ongkos mebeler tersebut kepada perusahaan. Sebaliknya, perusahaan mebeler juga mempunyai kewajiban, yaitu menyerahkan mebeler sebagaimana diperjanjikan dan mempunyai hak yaitu menerima biaya/ongkos mebeler.

Keseluruhan pihak yang berkaitan dengan obyek sengketa baik secara langsung maupun tidak langsung harus dimasukkan dalam gugatan. Tidak digugatnya pihak-pihak tersebut mengakibatkan gugatan tidak dapat diterima. Dalam hukum acara perdata tidak dikenal istilah turut penggugat, melainkan turut tergugat. Di sebutkan sebagai turut tergugat dimaksudkan agar orang-orang, bukan para pihak yang bersengketa (penggugat dan tergugat) demi lengkapnya pihak-pihak, maka orang-orang bukan pihak yang bersengketa tersebut harus diikutsertakan dalam gugatan penggugat sekedar untuk tunduk dan taat terhadap putusan hakim. Hal ini telah menjadi suatu yurisprudensi sebagaimana diputus dalam Putusan Mahkamah Agung tanggal 28 Januari 1976 No. 201 K/ Sip/ 1974. ${ }^{11}$

Ketiga, mengalami kerugian secara langsung dan nyata. Kerugian secara langsung dan nyata dalam hal ini berarti bahwa pihak yang mengajukan tuntutan hak haruslah pihak yang mempunyai dasar hukum dan kepentingan yang cukup atas hubungan hukum yang terjadi, se-

${ }^{11}$ Chidir Ali, 1985, Yurisprudensi Hukum Acara Perdata Indonesia, Yogyakarta: CV Nur Cahya, hlm. 218 
bagai contoh adalah A berhutang kepada $B$ sebesar Rp. 10.000.000,-. Setelah jatuh tempo A tidak membayar hutangnya juga. Dalam hal ini, $C$ yang merupakan adik dari B tidak dapat mengajukan gugatan kepada $A$ atas piutang yang dimiliki kakaknya (B), karena disini C tidak mempunyai dasar hukum dan kepentingan yang cukup untuk mengajukan gugatan.

\section{Class Action}

Gugatan secara class action atau gugatan kelompok telah lama dikenal dan berlaku di negara-negara yang menganut sistem hukum Common Law, seperti Inggris dan negara bekas jajahannya. Class action merupakan sinonim dari class suit atau representative action, ${ }^{12}$ yang memiliki karakteristik : pertama, gugatan diajukan oleh satu atau beberapa orang yang bertindak sebagai wakil kelompok, kedua, wakil kelompok bertindak atas nama mereka dan sekaligus untuk dan atas nama kelompok yang diwakili, ketiga, dalam gugatan tidak perlu disebutkan semua identitas anggota kelompok yang diwakili, akan tetapi cukup didefinisikan identifikasi anggota kelompok secara spesifik, keempat, anggota kelompok dengan wakil kelompok mempunyai kesamaan fakta dan dasar hukum yang melahirkan kesamaan kepentingan (common interest), kesamaan penderitan (common grievance), dan apa yang dituntut memenuhi syarat untuk kemanfaatan bagi seluruh anggota.

Class action menurut Black's Law Dictionary adalah sekelompok besar orang yang berkepentingan dalam suatu perkara, satu atau lebih dapat menuntut atau dituntut mewakili kekompok besar orang tersebut tanpa perlu menyebut satu peristiwa satu anggota yang diwakili. Class action bisa merupakan suatu metode bagi orang perorangan yang mempunyai tuntutan sejenis untuk bergabung bersama mengajukan tuntutan agar lebih efisien, dan seseorang yang akan turut serta dalam class action harus memberikan persetujuan kepada perwakilan. Tujuan class action secara mendasar

\footnotetext{
12 Yahya Harahap, 2005, Hukum Acara Perdata Gugatan, Persidangan, Penyitaan, Pembuktian dan Putusan Pengadilan, Jakarta: Sinar Grafika, hlm. 137
}

antara lain adalah efisiensi perkara, proses berperkara yang ekonomis, menghindari putusan yang berulang-ulang yang dapat berisiko adanya putusan inkonsistensi dalam perkara yang sama.

Di Indonesia, class action telah mendapat pengaturan dalam PERMA No. 1 Tahun 2002 tentang Acara Gugatan Perwakilan Kelompok. Gugatan perwakilan kelompok atau class action merupakan suatu prosedur pengajuan gugatan, dimana 1 (satu) orang atau lebih yang mewakili kelompok mengajukan gugatan untuk dirinya sendiri dan sekaligus mewakili sekelompok orang yang jumlahnya banyak, yang memiliki kesamaan fakta atau kesamaan dasar hukum antara wakil kelompok dan anggota kelompoknya. ${ }^{13}$

Berdasarkan pengertian tersebut, maka unsur-unsur class action terdiri dari, pertama, class action merupakan mekanisme pengajuan gugatan. Class action merupakan mekanisme pengajuan tuntutan hak selain mekanisme pengajuan tuntutan hak yang diatur dalam HIR, Rbg maupun Rv. Tuntutan hak sebagaimana telah dijelaskan sebelumnya, dapat disebabkan karena wanprestasi mapun perbuatan melawan hukum. Namun demikian, class action cenderung disebabkan oleh adanya perbuatan melawan hukum.

Kedua, terdapat wakil Kelompok (Class Representatif). Wakil kelompok merupakan satu orang atau lebih yang menderita kerugian, yang mengajukan gugatan sekaligus mewakili kelompok orang yang lebih banyak jumlahnya. Kedudukan dan kapasitas wakil kelompok adalah sebagai kuasa menurut hukum (legal mandatory) atau wettelijke vertegenwoordig, yaitu suatu kewenangan yang diberikan oleh peraturan perundang-undangan (dalam hal ini adalah PERMA No. 1 Tahun 2002) yang memberi hak dan kewenangan bagi wakil kelompok sebagai kuasa kelompok demi hukum. Dengan demikian, kuasa yang dimiliki oleh wakil kelompok tidaklah memerlukan surat kuasa dari anggota kelompok yang diwakilinya, selain itu tidak di perlukan persetujuan dari anggota kelompok

\footnotetext{
${ }^{13}$ Pasal 1 huruf a PERMA No. 1 Tahun 2002 tentang Acara Gugatan Perwakilan Kelompok
} 
untuk mewakili mereka ${ }^{14}$ Dalam hal ini, bagi anggota kelompok yang tidak setuju atau berkeberatan, dapat mengajukan hak opting out yang menyatakan dirinya keluar sebagai anggota kelompok. Sekalipun wakil kelompok bertindak sebagai kuasa menurut hukum bagi anggota kelompok, namun demikian, wakil kelompok juga dapat menunjuk kuasa baginya (Pasal 2 huruf $\mathrm{d}$ PERMA No. 1 Tahun 2002).

Ketiga, terdapat anggota kelompok (Class Member). Anggota kelompok merupakan sekelompok orang dalam jumlah banyak yang menderita kerugian, yang kepentingannya diwakili oleh wakil kelompok di pengadilan. PERMA No. 1 Tahun 2002 tidak menjelaskan batasan minimal jumlah anggota kelompok. Berkaitan dengan anggota kelompok, PERMA No. 1 Tahun 2002, hanya menjelaskan bahwa Jumlah anggota kelompok sedemikian banyak sehingga tidaklah efektif dan efisien apabila gugatan dilakukan secara sendiri-sendiri atau secara bersama-sama dalam satu gugatan. Oleh karena itu, jika anggota kelompok jumlahnya sedikit, misal 5 atau 10 orang, maka hal ini dapat di gunakan sebagai alasan untuk menolak gugatan class action. Namun demikian, menurut Yahya Harahap, ${ }^{15}$ penerapannya kasuistik dan harus di pertimbangkan dengan seksama faktor efektivitas dan efisiensi penyelesaian perkara yang bersngkutan.

Ketiga, memiliki kesamaan peristiwa/ fakta dan dasar hukum (commonality). Wakil kelompok dengan anggota kelompok harus terdapat kesamaan fakta dan kesamaan hukum sebagai akibat tindakan tergugat. Namun demikian, kesamaan fakta dan dasar hukum harus persis serupa secara mutlak, akan tetapi di mungkinkan adanya perbedaan, dengan syarat perbedaan tersebut tidak substansial dan prinsipiil.

Keempat, terdapat kerugian. Pihak wakil kelompok (class repesentatif) maupun anggota kelompok (class members) harus benar-benar atau secara nyata mengalami kerugian atau diistilahkan concrete injured parties.

\footnotetext{
${ }^{14}$ Pasal 4 PERMA No. 1 Tahun 2002 tentang Acara Gugatan Perwakilan Kelompok

${ }^{15}$ Ibid., hlm. 147
}

Keenam, terdapat tuntutan sejenis (typicallity). Tuntutan (bagi plaintiff class action) maupun pembelaan (bagi defedant class action) dari seluruh anggota yang diwakili (class members) haruslah sejenis. Pada umumnya dalam class action, jenis tuntutan yang dituntut adalah pembayaran ganti kerugian.

Berdasarkan unsur-unsur tersebut, yang dapat mengajukan gugatan dengan mekanisme class action adalah sekelompok orang yang jumlahnya banyak dan memiliki kesamaan fakta dan dasar hukum, sehingga apabila diajukan secara biasa (mekanisme gugatan sebagaimana diatur dalam HIR/Rbg) mengakibatkan proses pemeriksaan menjadi tidak efektif dan efisien. Pihak yang digugat dalam class action (penggugat) dapat berupa orang maupun badan hukum (badan hukum publik maupun privat).

\section{Pengajuan Gugatan oleh Lembaga Swadaya Mayarakat (Legal Standing)}

Tidak sedikit praktisi hukum yang mencampuradukkan antara pengertian gugatan perwakilan kelompok (class action) dan konsep hak gugat lembaga swadaya masyarakat (LSM). Sesungguhnya gugatan perwakilan kelompok/class action dan hak gugat LSM memiliki perbedaan. Legal standing merupakan hak gugat yang di miliki oleh LSM (Lembaga Swadaya masyarakat). Hukum nasional, secara materiil, telah mengatur hak gugat organisasi (legal standing/ius standing), namun hukum acara yang ditunjuk sebagai hukum formil yang mempertahankan hukum materiil tersebut belum diatur. Legal standing ini secara materiil diatur dalam beberapa undang-undang, yaitu Pasal 37 Undangundang No. 23 Tahun 1997 tentang Pengelolaan Lingkungan Hidup, Pasal 71 ayat (1) Undangundang No. 41 Tahun 1999 tentang Kehutanan dan Pasal 46 Undang-undang No. 8 Tahun 1999 tentang Perlindungan Konsumen.

Dalam mekanisme gugatan legal standing, LSM sebagai penggugat bukan sebagai pihak yang mengalami kerugian nyata. Namun karena kepentingannya, LSM ini kemudian mengajukan gugatan. Misalkan dalam perkara perlindungan lingkungan hidup, LSM sebagai penggugat mewakili kepentingan perlindungan lingkungan hi- 
dup yang perlu diperjuangkan karena posisi lingkungan hidup sebagai ekosistem sangat penting. Lingkungan hidup tentu tidak dapat memperjuangkan kepentingannya sendiri karena sifatnya yang in-animatif (tidak dapat berbicara) sehingga perlu ada pihak yang memperjuangkan.

Berdasarkan hal tersebut di atas, dapat diuraikan karakteristik mekanisme gugatan legal standing. Pertama, pihak penggugat. Pihak yang dapat mengajukan tuntutan hak dengan menggunakan mekanisme legal standing hanyalah lembaga swadaya masyarakat (LSM). Hanya LSM yang anggaran dasarnya meliputi perbuatan yang dilanggar oleh tergugat saja yang dapat mengajukan legal standing dan pelanggaran oleh tergugat tersebut merupakan bagian kegiatan LSM yang diatur dalam anggaran dasar LSM tersebut, sebagai contoh, dalam pencemaran lingkungan hidup, maka yang dapat mengajukan gugatan hanya LSM yang menurut anggaran dasarnya bergerak dalam bidang lingkungan hidup.

Kedua, pihak tergugat. Pihak yang dapat digugat melalui mekanisme legal standing pada dasarnya meliputi seluruh subjek hukum, baik orang perorangan dan badan hukum (badan hukum publik maupun privat). Ketiga, dalil tuntutan hak. Tuntutan hak yang dapat diajukan dalam mekanisme gugatan legal standing adalah terkait dengan perbuatan melawan hukum yang dilakukan oleh subjek hukum. Dalam kasus lingkungan misalnya, sebuah perusahaan digugat karena telah membuang limbah yang mengakibatkan pencemaran lingkungan. Pencemaran lingkungan ini dikualifikasikan sebagai perbuatan melawan hukum.

Keempat, petitum. Dalam legal standing tidak dikenal tuntutan ganti kerugian uang. Ganti rugi dapat dimungkinkan sepanjang atau terbatas pada ongkos atau biaya yang telah di keluarkan oleh organisasi tersebut. Subjek hukum yang digugat hanya diminta untuk melakukan atau tidak melakukan suatu perbuatan tertentu. Dalam kasus lingkungan hidup tersebut di atas misalnya, pihak tergugat dituntut untuk tidak melakukan pencemaran lagi dan memulih- kan kembali ekosistem yang telah rusak sebagai akibat pembuangan limbah.

\section{Citizen Law Suit atau Actio Popularis}

Beberapa sarjana berpendapat bahwa citizen law suit hampir sama dengan actio popularis yang dikenal di common law. Menurut Gokkel ${ }^{16}$, actio popularis adalah gugatan yang dapat diajukan oleh setiap orang, tanpa ada pembatasan, dengan pengaturan oleh negara. Menurut Kotenhagen-Edzes ${ }^{17}$, dalam actio popularis setiap orang dapat menggugat atas nama kepentingan umum dengan menggunakan Pasal 1401 Niew BW (Pasal 1365 BW). Dari kedua pendapat tersebut dapat disimpulkan bahwa actio popularis adalah suatu gugatan yang dapat diajukan oleh setiap orang terhadap suatu perbuatan melawan hukum, dengan mengatasnamakan kepentingan umum, berdasarkan peraturan perundang-undangan yang mengatur adanya prosedur tersebut.

Citizen law suit sendiri merupakan akses orang perorangan warga negara untuk kepentingan publik termasuk kepentingan lingkungan mengajukan gugatan dipengadilan guna menuntut agar pemerintah melakukan penegakan hukum yang diwajibkan kepadanya atau untuk memulihkan kerugian publik yang terjadi. Pada dasarnya citizen law suit merupakan suatu hak gugat warga negara yang dimaksudkan untuk melindungi warga negara dari kemungkinan terjadinya kerugian sebagai akibat dari tindakan atau pembiaran omisi dari negara atau otoritas negara. Menurut pendapat Michael D Axline ${ }^{18}$, citizen law suit memberikan kekuatan kepada warga negara untuk menggugat pihak tertentu (privat) yang melanggar undang-undang selain kekuatan kepada warga negara untuk menggugat negara dan lembaga-lembaga (federal) yang melakukan pelanggaran Undang-undang atau yang gagal dalam memenuhi kewajibannya dalam pelaksanaan Undang-undang.

${ }^{16}$ Sundari, 2002, Pengajuan Gugatan Secara Class Action (Suatu Studi Perbandingan dan penerapannya di Indonesia), Yogyakarta: Universitas Atma Jaya, hlm. 12

17 Ibid

${ }^{18}$ Michael D Axline.h dalam www.legal-dailythouht.info/2009/02/antara-citizen-law-suit-dan-classaction/2, 29 Februari 2009, Antara Citizen Lawsuit dan Class Action, diakses pada tanggal 3 Maret 2009 
Berdasarkan pemikiran tersebut, maka dapat diinterpretasikan, bahwa citizen law suit pada intinya adalah mekanisme bagi warga negara untuk menggugat tanggung jawab penyelenggara negara atas kelalaian dalam memenuhi hak-hak warga negara. Kelalaian tersebut didalilkan sebagai perbuatan melawan hukum, sehingga citizen law suit diajukan pada lingkup peradilan umum dalam hal ini perkara Perdata. Oleh karena itu, atas kelalaiannya, dalam petitum gugatan, Negara dihukum untuk mengeluarkan suatu kebijakan yang bersifat mengatur umum (regeling). Hal ini dimaksudkan agar kelalaian tersebut tidak terjadi lagi di kemudian hari.

Berdasarkan hal tersebut, maka dapat diketahui karakteristik dari gugatan citizen law suit. Pertama, pihak penggugat. Pihak penggugat dalam citizen law suit adalah warga negara, baik perorangan maupun sekelompok orang, yang bertindak mengatasnamakan warga negara. Penggugat dalam hal ini cukup membuktikan bahwa dirinya adalah warga negara Indonesia. Berbeda halnya dengan gugatan biasa maupun class action, dalam citizen law suit, penggugat tidak harus merupakan kelompok warga negara yang dirugikan secara langsung oleh negara, oleh karena itu penggugat tidak harus membuktikan kerugian materiel apa yang telah dideritanya sebagai dasar gugatan. Penggugat dalam hal ini mewakili warga negara Indonesia, tidak perlu dipisah-pisah menurut kelompok kesamaan fakta dan kerugian sebagaimana dalam gugatan class action. Dalam mekanisme pengajuan gugatan citizen law suit tidak memerlukan adanya suatu notifikasi option out setelah gugatan didaftarkan sebagaimana diatur dalam PERMA No. 1 Tahun 2002 tentang Acara Gugatan Perwakilan Kelompok.

Dalam prakteknya, di Indonesia yang didasarkan pada pengaturan di beberapa negara common law, citizen law suit cukup hanya dengan memberikan notifikasi berupa somasi kepada penyelenggara negara. Isi somasi adalah bahwa akan diajukan suatu gugatan citizen law suit terhadap penyelenggara negara atas kelalaian negara dalam pemenuhan hak-hak warga negaranya dan memberikan kesempatan bagi negara untuk melakukan pemenuhan jika tidak ingin gugatan diajukan. Somasi tersebut harus diajukan selambat-lambatnya 2 (dua) bulan sebelum gugatan didaftarkan, namun karena belum ada satupun peraturan formal yang mengatur hal tersebut, maka ketentuan ini tidak berlaku mengikat. ${ }^{19}$

Kedua, pihak tergugat. Tergugat dalam citizen law suit adalah Penyelenggara Negara, mulai dari Presiden dan Wakil Presiden sebagai pimpinan teratas, Menteri dan terus sampai kepada pejabat negara di bidang yang dianggap telah melakukan kelalaian dalam memenuhi hak warga negaranya. Dengan kata lain, pihak selain penyelenggara negara tidak boleh dimasukkan sebagai pihak baik sebagai tergugat maupun turut tergugat. Hal ini merupakan ciri khas dari citizen law suit. Apabila ada pihak lain (individu atau badan hukum) yang ditarik sebagai tergugat/turut tergugat, maka gugatan tersebut menjadi bukan citizen law suit lagi. Gugatan tersebut menjadi gugatan biasa yang tidak bisa diperiksa dengan mekanisme citizen law suit.

Ketiga, dalil tuntutan hak. Perbuatan melawan hukum yang didalilkan dalam gugatan adalah kelalaian penyelenggara negara dalam pemenuhan hak-hak warga negara. Kelalaian negara dalam hal ini dikualifikasikan sebagai perbuatan melawan hukum, karena negara telah lalai dalam melakukan kewajibannya untuk melindungi warga negaranya. Dalam hal ini harus diuraikan bentuk kelalaian apa yang telah dilakukan oleh negara dan hak warga negara apa yang gagal dipenuhi oleh negara. Selain itu, dalam pemeriksaan persidangan, penggugat harus membuktikan, bahwa negara telah melakukan perbuatan melawan hukum tersebut.

Keempat, petitum. Petitum dalam gugatan tidak boleh meminta adanya ganti rugi materiel, karena dalam hal ini, pihak penggugat mengajukan gugatannya karena negara tidak melakukan kewajibannya untuk melindungi warga negaranya. Petitum harus berisi permohonan agar negara mengeluarkan suatu kebijakan

\footnotetext{
${ }^{19}$ Arko Kanadianto, 23 Januari 2008, Konsep citizen lawsuit di Indonesia, http://kanadianto.wordpress.com/2008/ 01/23/konsep-citizen-lawsuit-di-indonesia/ diakses pada tanggal 2 Februari 2009
} 
yang mengatur umum (regeling) agar perbuatan melawan hukum berupa kelalaian dalam pemenuhan hak warga negara tersebut di masa yang akan datang tidak terjadi lagi. Sehubungan dalil gugatan disebabkan adanya kelalian negara, maka gugatan citizen law suit tidak boleh diajukan karena dikeluarkannya peraturan perundang-undangan maupun suatu keputusan tata usaha negara. Oleh karena itu, petitum gugatan citizen law suit tidak boleh berisi pembatalan atas suatu keputusan penyelenggara negara (keputusan tata usaha negara) yang bersifat konkrit, individual dan final, karena hal tersebut merupakan kewenangan dari Peradilan Tata Usaha Negara.

Beberapa kasus gugatan citizen law suit yg pernah didaftarkan di Indonesia antara lain: pertama, gugatan citizen law suit atas nama Munir Cs atas penelantaran negara terhadap Tenaga Kerja Indonesia (TKI) yg dideportasi di Nunukan. Gugatan ini dikabulkan Majelis Hakim Jakarta Pusat dengan Ketua Majelis Andi Samsan Nganro. Hasilnya adalah UU Nomor 39 Tahun 2004 tentang Penempatan dan perlindungan Tenaga Kerja Indonesia. Ini merupakan gugatan citizen law suit pertama yang muncul di Indonesia. Kedua, gugatan citizen law suit atas kenaikan BBM oleh LBH APIK, akan tetapi gugatan ini ditolak, bentuk citizen law suit tidak diterima Majelis Hakim PN Jakarta Pusat. Ketiga, gugatan citizen law suit atas Operasi Yustisi oleh LBH Jakarta, gugatan ini juga ditolak, bentuk citizen law suit tidak diterima Majelis Hakim PN Jakarta Pusat.

\section{Penutup}

\section{Simpulan}

Berdasarkan uraian di atas, maka dapat di simpulkan karakteristik gugatan biasa yaitu penggugat dan tergugat merupakan subjek hukum, baik orang maupun badan hukum dengan dalil tuntutan hak berupa wanprestasi maupun perbuatan melawan hukum. Tuntutannya adalah ganti kerugian maupun melakukan atau tidak melakukan perbuatan tertentu kepada tergugat, sehingga dalam hal ini penggugat harus mempunyai perbuatan dan kerugian yang terjadi sebagai akibat perbuatan tergugat.
Class action diajukan manakala jumlah penggugatnya adalah banyak (numerous), sedangkan yang mengajukan gugatan adalah wakil kelompok, yang mewakili kepentingannya sendiri maupun anggota kelompoknya, dengan tuntutan berupa ganti kerugian. Pihak yang dapat digugat adalah seluruh subjek hukum, baik orang maupun badan hukum.

Gugatan LSM atau legal standing merupakan mekanisme pengajuan gugatan oleh LSM sebagai akibat pelanggaran atau adanya perbuatan melawan hukum yang dilakukan pihak lain yang merupakan kegiatan perlindungan yang dilakukan LSM tersebut sebagaimana di atur dalam anggaran dasar.

Gugatan citizen lawsuit atau actio popularis, merupakan gugatan yang diajukan oleh seorang atau lebih warga negara atas nama seluruh warga negara yang ditujukan kepada negara, dalam hal ini penyelenggara negara, sebagai akibat adanya perbuatan melawan hukum, pada umumnya berupa penelantaran hak-hak warga negara, dengan maksud agar segera dibentuk aturan hukum, sehingga hakhak warga negara dapat terlindungi. 